\title{
ASSESSMENT OF KNOWLEDGE AND PRACTICE REGARDING INFECTION CONTROL MEASURES AMONG STAFF NURSES \\ Sahar Elsayed Fawzi ${ }^{(1)}$,Wafaa Fathi Sleem ${ }^{(2)}$, Eman Saleh Shahien ${ }^{(3)}$, Hind Abdullah Mohamed ${ }^{(4)}$
}

Bachelor Science Nursing, Faculty of Nursing-Assuit University ${ }^{(1)}$, Assistant Prof of Nursing Administration, Faculty of Nursing-Mansoura University ${ }^{(2)}$ Assistant Prof of Medical Surgical Nursing, Faculty of Nursing - Port-Said University ${ }^{(3)}$ ), Lecture of Nursing Administration, Faculty of Nursing-Port-Said University ${ }^{(4)}$

\begin{abstract}
Background: Nurses are often exposed to various infections during the course of carrying out their nursing activities. Therefore nurses should have knowledge and strict adherence to infection control practice. Aim: The study aimed to assess the level of knowledge and level of practice of infection control measures among staff nurses. Methods: A descriptive correlation research design was utilized with total sample of (245) staff nurses who were working in Meniet El-Nasr Central Hospital that affiliated to Ministry of Health. Tools of data collection: Self-administered questionnaire sheet was used to assess nurses' knowledge about infection control measures and an observation checklist that was used for assessing staff nurses' practice. Results: Revealed that $85.3 \%$ of staff nurses had unsatisfactory knowledge and $71.0 \%$ of them had inadequate practice regarding infection control measures. Conclusion: The findings pointed to, the majority of the staff nurses had unsatisfactory knowledge and inadequate practice regarding infection control measures. Recommendations: Training course program is necessary to increase nurses' knowledge and practice towards nosocomial infection control measures regularly.,
\end{abstract}

Keywords: Infection control, Knowledge, Practice, Staff Nurses 


\section{INTRODUCTION}

Infections acquired in health care are most commonly occurs in health care delivery worldwide. Hundreds of millions of patients are affected by health careassociated infection, worldwide each year, resulting in significant mortality and financial losses for health systems (Varshney et al., 2014). Infection is the invasion and multiplication of microorganisms such as bacteria, virus, and parasites that are not normally present within the body. (Faris and Hassan, 2016).

Nosocomial infections are defined as an infection acquired during or as a result of hospitalizations. The patients neither have these infections not are incubating this infection on admission. Generally, a patient who develops an infection after 48 hours of hospital admission is considered to have a nosocomial infection. Some nosocomial infection may not as disease immediately and can manifest event after discharge (Teshager et al., 2015).

Nosocomial infection (NI), or hospital-acquired infection or Health-careassociated infection (HCAI) refers to infection that is acquired during the process of care and not manifested at the time of admission to a hospital or other health-care facility. It has been estimated that the risk of health care-associated infection is 2 to 20 times higher in developing countries compared to developed countries and $5 \%$ and $10 \%$ of patients admitted to hospitals in developed countries acquire these infections (WHO, 2008).

Infection occurs in hospitals and health post because patients who visit these facilities have often much different illness; while in the hospital or health post, they may transmit their organisms through direct or indirect contact. Factors which make a person more likely to get infect are of certain ages (newborn's, elderly) underlying diseases (diabetes, malnourishment). Drug therapy (antibiotics, steroids) and invasive procedures (surgery and catheterization) (Al-Jubouri, 2014).

Two modes of contact transmission exist, direct and indirect contact transmission. Direct contact transmission consists of a direct body surface to body surface contact and physical transfer of bacteria between a susceptible host and an infected or colonized individual, for example bathing or turning a patient. Indirect contact 
transmission involves contact of a susceptible host with contaminated objects like medical instruments, dressings, used gloves (Amoran and Onwube, 2013).

Nosocomial infections contribute greatly to morbidity, mortality and often the length of stay in the hospitals with enormous additional costs by patients and their families (Cardo et al., 2010). Nosocomial infection is the common but often avoidable complication of health care which has major the patient and the health care service. It has been estimated that up to one-third of attired infection could be prevented by improved infection control practice (Siegel, 2007).

Therefore, it is important for all healthcare workers, patients, their family members, friends and close contacts to adhere to the infection control guidelines strictly. It is also imperative for health care administrators to ensure implementation of the infection control program in health care facilities (Patel, et al., 2009). In addition, nurses spend more time with patients in the ward than any other member of the health team, so they play an important role in infection control and prevention. Educating patients may decrease their risk of becoming infected or may decrease the sequelae of infection. Using appropriate barrier precautions, observing prudent hand hygiene, and ensuring the aseptic care of intravenous catheters and other invasive equipment also assists in reducing infections (Smeltzer, et al., 2010).

\section{AIM OF STUDY:}

The aim of this study is to assess knowledge and practice regarding infection control measures among staff nurses.

\section{SUBJECT AND METHODS:}

Research design: A descriptive correlational research design was used for this study.

Study setting: The present study was conducted in Meniet El-Nasr Central Hospital that affiliated to Ministry of Health at Dakahlia Governorate. The hospital consists of 250 beds, 5 floors, and 10 departments.

Subjects: A sample with total number (245) staff nurses were selected by simple random sampling. The participants were chosen with no age limit, all available educational level and approval to share in the study. 
Sample: the sample size was determined with $95 \%$ confidence level according to

(Pourhoseingholi et al., 2013)

$$
\underline{Z 2 \times p(1-p)}
$$

$d 2$

Where:

Z2-3.84

D2-.0025

p- Assessment result of previous research $\quad$ P_80\%

$\mathbf{P}(\mathbf{1 - P})=0.16$ of practice

$\underline{3.84 \times 0.8(1-0.8)}$

0.0025

$n=(245)$

Accordingly, the required sample size is 245 staff nurses.

\section{Tool for data collection:}

\section{The tool consists of the following three parts:}

Part1: Personal and Job Characteristics of the study subjects. It comprises: nurses age, gender, years of experience, qualification and work place.

Part2: Self-administered Knowledge Questionnaire Sheet to assess the exact level of knowledge that staff nurses had about infection control measures, and it consist of 45 items, divided into two parts, questions related to hospital ( 15 number ) and staff nurses knowledge about nosocomial infection. (35number)

\section{Scoring system:}

Subjects responses were measured by giving a score of (two) for the correct complete answer, (one) for the correct incomplete answer \& (zero) for the incorrect answer. Knowledge was considered satisfactory if the percent score was $\geq 60 \%$ and unsatisfactory if it was $<60 \%$ (Abd Aziz, 2008).

Part3: observation checklist that was used for assessing nurses' practice regarding infection control measures, and it consists of 119 items, divided into two parts, General infection control precaution and Specific infection control precaution.

\section{Scoring System:}

The items observed to be done were scored "one" and the items not applicable and not done were scored "zero". The practice was considered adequate if the percentage score was $\geq 60 \%$ and inadequate if it was $<60 \%$ (Sliman, 2005). 


\section{Content Validity:}

A pilot study was carried out on $10 \%$ of the sample in the study setting that were excluded from the study sample. The purposes of the pilot study were to test the applicability and, feasibility and clarity of the study tools and it served to estimate the time needed to complete the tools. It also helped to find out any obstacles and problems that might interfere with data collection.

\section{Ethical consideration:}

Before conduction of the study, an official letter was taken from the Dean of the Faculty of Nursing in Port Said University to the Director of Meniet Elnasr Hospital. After an explanation of the purpose of the study, a written permission was secured. On data collection, a verbal agreement was taken from every nurse, after a clear and simple explanation of the purpose of the study. Also the researcher assured the respondents about anonymity of their answers, and that the information will be used for scientific research only and will be treated as confidential.

Field work: The researcher was interviewing nurses in the unit in order to collect data. Five days per week were specified for data collection (Sunday, Monday, Tuesday, Wednesday \& Thursday) from 12 to 2 PM. Every nurse was asked to fill in the designed questionnaire sheet by herself in presence of the researcher to answer any questions that the nurse might had about the questionnaire. All data were remained confidential and be anonymous using a series of research codes. All recordings or transcripts were containing corresponding codes. Research codes are only known by the researcher.

The observational checklist was fulfilled in every unit using observational techniques for 3 different shifts to assure and verify the result and to calculate the average score of each item in the observational checklist. The observation was done throughout the morning, evening and night shifts. The field work lasted for 8 months throughout the period from February 2015 to the end of September 2015. 


\section{Statistical analysis:}

The raw data were coded and transformed into coding sheet. The results were checked. Then, the data were entered into SPSS system files (SPSS package version 20.0) using frequency\& percentage for quantitative data, $\mathrm{x}_{2}$ test was used, statistical significant was considered at the 0.05 level.

\section{RESULTS:}

Table (1): illustrates the personal and job characteristics of the studied staff nurses. The table reveals that $40.8 \%$ of staff nurses were in the age group ranged from 25 to less than 30 years with the mean age of $26.6 \pm 4.5$ years old. The most of them $(98.0 \%)$ were female. Also, 52.7\% had technical institute diploma. Regarding years of experience, $43.7 \%$ of them had years of experience less than five years.

Table (2): displays that $76.3 \%$ of the studied staff nurses had satisfactory knowledge about nosocomial infection control. On the other hand $2.4 \%$ of them had satisfactory knowledge about urinary tract infection as a type of nosocomial infection.

Figure (1): shows that, $85.3 \%$ of staff nurses had unsatisfactory of total level of knowledge about infection control, while $14.7 \%$ of them had satisfactory of total level of knowledge.

As shown in table (3), illustrates that $88.2 \%$ of the studied staff nurses used personal hygiene. Also, $81.2 \%$ of them used infection control measures for specimen collection/transportation. And $62 \%$ of them followed cleaning, disinfection, and sterilization procedures.

Table (4): indicates that $31.0 \%$ of the studied staff nurses followed infection control when using endotracheal suctioning machine. While, none of the studied staff nurses $100 \%$ didn't follow prevention and control of wound infection pre and postoperative which considered as an inadequate practice level. Also, $2.4 \%$ of them followed infection control for prevention and control of urinary tract infection.

As shown in table (5) shows that adequate total general practice level of infection control measures was $47.3 \%$. And adequate total specific practice level of infection control measures was $18.8 \%$. Meanwhile, the adequate total practice level of infection control measures was $29 \%$.

Table (6) shows that there was no statistically significant relation between the staff nurses' knowledge level and their areas of practice level. 
Table (1): Personal and job characteristics of staff nurses in the study sample $(n=245)$

\begin{tabular}{|c|c|c|}
\hline \multirow[b]{2}{*}{ Personal \& job characteristics } & \multicolumn{2}{|c|}{ Staff nurses } \\
\hline & No. & $\%$ \\
\hline Age: & & \\
\hline$<25$ & 92 & 37.6 \\
\hline $25<30$ & 100 & 40.8 \\
\hline $30+$ & 53 & 21.6 \\
\hline Range & \multirow{2}{*}{\multicolumn{2}{|c|}{$\begin{array}{c}20.0-48.0 \\
26.6 \pm 4.5\end{array}$}} \\
\hline Mean \pm SD & & \\
\hline Gender: & & \\
\hline Male & 5 & 2.0 \\
\hline Female & 240 & 98.0 \\
\hline \multicolumn{3}{|l|}{ Nursing qualifications: } \\
\hline Bachelor nursing & 62 & 25.3 \\
\hline Technical institute diploma & 129 & 52.7 \\
\hline Secondary nursing diploma & 54 & 22.0 \\
\hline \multicolumn{3}{|l|}{ Experience years: } \\
\hline$<5$ & 107 & 43.7 \\
\hline $5<10$ & 79 & 32.2 \\
\hline $10+$ & 59 & 24.1 \\
\hline Range & \multirow{2}{*}{\multicolumn{2}{|c|}{$\begin{array}{c}0.0-27.0 \\
6.4 \pm 5.1\end{array}$}} \\
\hline Mean \pm SD & & \\
\hline \multicolumn{3}{|l|}{ Department: } \\
\hline Emergency & 33 & 13.5 \\
\hline ICU & 40 & 16.3 \\
\hline Surgical & 32 & 13.1 \\
\hline Operating room & 11 & 4.5 \\
\hline Pediatrics & 15 & 6.4 \\
\hline Medical & 30 & 12.2 \\
\hline Obs/Gyne & 20 & 8.2 \\
\hline Incubator & 19 & 7.8 \\
\hline Hemodialysis & 45 & 18.4 \\
\hline
\end{tabular}


Table (2): Knowledge about infection control among staff nurses in the study sample $(\mathrm{n}=245)$

\begin{tabular}{||l|c|c||}
\hline \multicolumn{1}{|c|}{ Infection control knowledge } & No. & $\%$ \\
\hline Infection & 56 & 22.9 \\
Nosocomial infection definition & 34 & 13.9 \\
Nosocomial infection types: & & \\
$\quad$ Respiratory & 11 & 4.5 \\
Urinary & 6 & 2.4 \\
Blood & 52 & 21.2 \\
Nosocomial infection control & 187 & 76.3 \\
Infection control precautions & 87 & 35.5 \\
\hline
\end{tabular}

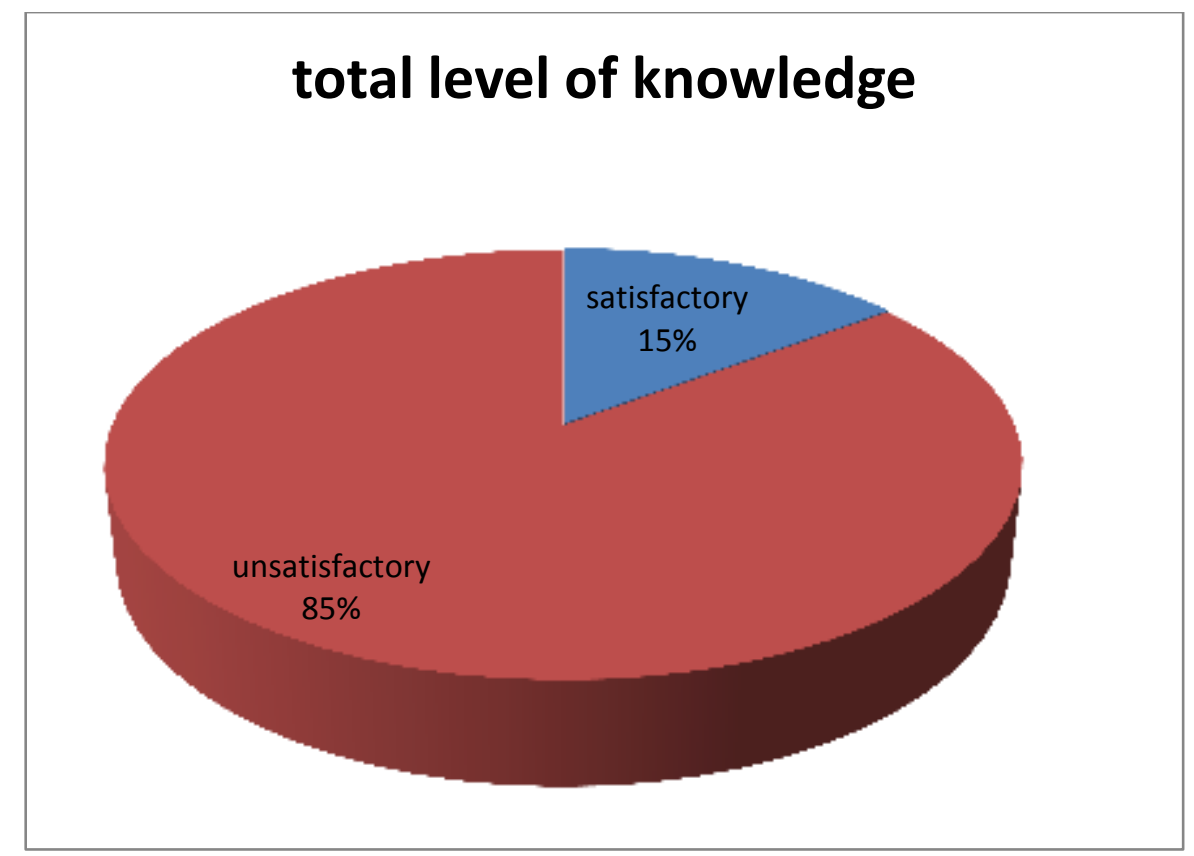

Figure (1):-Total Level of Knowledge Regarding Infection Control. 
Table (3): Practice level of general infection control measures as observed by staff nurses in the study sample $(n=245)$

\begin{tabular}{||l|c|c|l|c|c||}
\hline \multicolumn{1}{|c|}{$\begin{array}{c}\text { Adequate practice level } \\
(\mathbf{6 0 \% )}\end{array}$} & No. & $\mathbf{\%}$ & $\begin{array}{c}\text { In adequate practice level } \\
(<\mathbf{6 0 \%})\end{array}$ & No. & $\%$ \\
\hline Hand washing & 116 & 47.3 & Hand washing & 129 & 52.7 \\
\hline Protective clothing & 50 & 20.4 & Protective clothing & 195 & 79.6 \\
\hline Personal hygiene & 216 & 88.2 & Personal hygiene & 29 & 11.8 \\
\hline Handling sharps & 82 & 33.5 & Handling sharps & 163 & 66.5 \\
\hline $\begin{array}{l}\text { Cleaning/disinfection/ } \\
\text { Sterilization }\end{array}$ & 152 & 62.0 & $\begin{array}{l}\text { Cleaning/disinfection/ } \\
\text { Sterilization }\end{array}$ & 93 & 38.6 \\
\hline Handling/disposal of waste & 91 & 37.1 & Handling/disposal of waste & 154 & 62.9 \\
\hline Notification & 143 & 58.3 & Notification & 102 & 41.6 \\
\hline Isolation & 25 & 10.2 & Isolation & 220 & 89.8 \\
\hline $\begin{array}{l}\text { Specimen } \\
\text { collection/transportation }\end{array}$ & 199 & 81.2 & $\begin{array}{l}\text { Specimen } \\
\text { collection/transportation }\end{array}$ & 46 & 18.8 \\
\hline
\end{tabular}

Table (4): Practice level of specific infection control measures as observed by staff nurses in the study sample $(\mathrm{n}=245)$

\begin{tabular}{|c|c|c|c|c|c|}
\hline $\begin{array}{c}\text { Adequate practice level } \\
\qquad(\geq 60 \%)\end{array}$ & No. & $\%$ & $\begin{array}{l}\text { In adequate practice level } \\
\qquad(<60 \%)\end{array}$ & No. & $\%$ \\
\hline $\begin{array}{l}\text { Prevention/control of respiratory } \\
\text { infection }\end{array}$ & 17 & 6.9 & $\begin{array}{l}\text { Prevention/control of respiratory } \\
\text { infection }\end{array}$ & 228 & 93.1 \\
\hline \begin{tabular}{|l} 
Endotracheal suctioning: \\
\end{tabular} & & & Endotracheal suctioning: & & \\
\hline Suction machine & 76 & 31.0 & Suction machine & 169 & 69.8 \\
\hline Endotracheal suction & 18 & 7.3 & Endotracheal suction & 227 & 92.7 \\
\hline Total suctioning & 69 & 28.1 & Total suctioning & 176 & 71.8 \\
\hline $\begin{array}{l}\text { Prevention/control of wound } \\
\text { infection: }\end{array}$ & & & $\begin{array}{l}\text { Prevention/control of wound } \\
\text { infection: }\end{array}$ & & \\
\hline Pre-operative & 3 & 1.2 & Pre-operative & 242 & 98.8 \\
\hline Post-operative & 4 & 1.6 & Post-operative & 241 & 98.4 \\
\hline Total wound & 0 & 0.0 & Total wound & 245 & 100.0 \\
\hline Chest tubes & & & Chest tubes & & \\
\hline Medication and fluids & 59 & 24.1 & Medication and fluids & 186 & 75.9 \\
\hline $\begin{array}{l}\text { Prevention/control of urinary } \\
\text { infection }\end{array}$ & 6 & 2.4 & $\begin{array}{l}\text { Prevention/control of urinary } \\
\text { infection }\end{array}$ & 239 & 97.6 \\
\hline $\begin{array}{l}\text { Prevention/control of IV-device } \\
\text { related infection }\end{array}$ & 69 & 28.2 & $\begin{array}{l}\text { Prevention/control of IV-device } \\
\text { related infection }\end{array}$ & 176 & 71.8 \\
\hline
\end{tabular}


Table (5): Total practice level of infection control measures as observed by staff nurses in the study sample $(\mathrm{n}=245)$

\begin{tabular}{|l|c|c|}
\hline \multicolumn{1}{|c|}{ Total practice level } & No. & \% \\
\hline Total general: & & \\
Adequate & 116 & 47.3 \\
Inadequate & 129 & 52.7 \\
\hline Total specific: & 46 & \\
Adequate & 199 & 81.2 \\
Inadequate & & \\
Total practice: & 71 & 29.0 \\
Adequate & 174 & 71.0 \\
Inadequate & & \\
\hline
\end{tabular}

Table (6): Relation between staff nurses' knowledge level and areas of practice level

\begin{tabular}{|c|c|c|c|c|c|c|}
\hline \multirow{3}{*}{$\begin{array}{c}\text { Area of Practice } \\
\text { level }\end{array}$} & \multicolumn{4}{|c|}{ Knowledge level } & \multirow{3}{*}{$\mathbf{X}^{2}$} & \multirow{3}{*}{ p-value } \\
\hline & \multicolumn{2}{|c|}{ Satisfactory } & \multicolumn{2}{|c|}{ Unsatisfactory } & & \\
\hline & No. & $\%$ & No. & $\%$ & & \\
\hline \multicolumn{7}{|l|}{ General: } \\
\hline Adequate & 13 & 11.2 & 103 & 88.8 & \multirow{2}{*}{2.14} & \multirow{2}{*}{0.14} \\
\hline Inadequate & 23 & 17.8 & 106 & 82.2 & & \\
\hline \multicolumn{7}{|l|}{ Specific: } \\
\hline Adequate & 10 & 21.7 & 36 & 78.3 & \multirow{2}{*}{2.24} & \multirow{2}{*}{0.13} \\
\hline Inadequate & 26 & 13.1 & 173 & 86.9 & & \\
\hline \multicolumn{7}{|l|}{ Total: } \\
\hline Adequate & 7 & 9.9 & 64 & 90.1 & \multirow{2}{*}{1.86} & \multirow{2}{*}{0.17} \\
\hline Inadequate & 29 & 16.7 & 145 & 83.3 & & \\
\hline
\end{tabular}

\section{DISCUSSION:}

Nosocomial infection increase patients' morbidity, mortality, the length of hospital stay Therefore, knowledge and practice about the frequency and distribution of nosocomial infections are important to improve infection control measures as well as to develop effective preventive and curative strategies which, in turn, will help us in decreasing incidence, morbidity and mortality (Park, 2008). 
Nurses spend more time with patients in the ward than any other member of the health team. This increases their exposure to hospital environmental infection. So they play a key role in the management of nosocomial infection, they need to wash hands and wear personal protective equipment, and management of healthcare wastes in order for them to fulfill this function efficiently, it is important that they have adequate knowledge about the importance of control of nosocomial infection (Sliman, 2005).

In this respect, the current study was conducted to assess knowledge and practice of staff nurses regarding infection control in Meniet El-Nasr central hospital affiliated to ministry of health through; assess staff nurses' knowledge level; and assess staff nurses' practice level; find out the relationship between knowledge level and practice level among staff nurses.

Regarding staff nurses' knowledge level, the study finding of the current study showed that the more than three quarter of staff nurses had unsatisfactory knowledge regarding nosocomial infection. This may be due to the poor supervision of the nurse, inadequate training in the area of nosocomial infection, the absence of regular group discussion to refresh their knowledge regarding nosocomial infection, lack of motivation.

the same viewpoint the study finding of of Ezz El-Deen (2010); Al-Jubouri (2014) who asserted, that only less than one-third of staff nurses had total satisfactory knowledge about nosocomial infection. And the low knowledge of the staff nurses attributed to lack of motivation and involvement of nurses in the hospital, lack or irregular training in this area, and thus staff nurses are expected to have no theoretical background. Additionally, knowledge about basic principles of infection and its transmission was very low among staff nurses.

On the same line, Abd El-Azeem (2013) who assess nursing knowledge and performance regarding infection control measures with the central venous catheter, found that the majority of nurses experienced deficits in their knowledge regarding infection control, and this deficit was corrected after implementation of the educational programs.

Similar study findings were reported by Fashafsheh et al., (2015) who assess knowledge and practice of nursing staff towards infection control measures in the Palestinian hospitals, stated that approximately two-thirds of the study sample had low 
knowledge about infection control. Education is a critical element in the training of all health care workers, particularly in countries where there is a lack of formal and wellorganized infection control programs. The study finding is inconsistent with El-Sayed et al., (2015) who reported that slightly more than half of staff nurses working in the burn unit in Cairo University had satisfactory knowledge about infection control.

Regarding staff nurses' practice level, the study finding revealed that the majority more than two third of staff nurses had inadequate practice in most areas of nosocomial infection. These findings could be explained by the study result which proved that the staff nurses had unsatisfactory knowledge in areas of infection control and may be attributed to lack of practical clinical guidance in relation to basic principles of infection control precautions. The study finding was consistent with $\boldsymbol{E} z \boldsymbol{z}$ El-Deen (2010) who found that none of the studied nurses had the adequate performance of infection control and attributed these result to the lack of knowledge. Moreover, the study finding parallel to El-sayed et al., (2015) who concluded that most studied sample had an unsatisfactory level of practice regarding infection control measures.

The study finding inconsistent with Gizaw et al., (2014) who assess knowledge and practices regarding infection control and universal precautions among staff nurses in Ethiopia, and found that knowledge of universal precautions measures was high more than three-quarter for nurses, although the practice was adequate for the nurses more than three-quarter. Also, the current study was in contrast with Fashafsheh et al., (2015) mentioned that the majority more than three-quarter of the studied staff nurses sample had adequate practice.

Nurses and other healthcare personnel must take precautions to control infections when caring for all clients. These precautions are called standard precautions, measures for reducing the risk of transmitting pathogens from both recognized and unrecognized sources of infection. Health care providers also must apply principles of medical asepsis, such as hand hygiene for clients known to be or suspected of being infected with highly transmissible pathogens, nurses and other healthcare personnel must also follow transmission-based precautions. Because these precautions may isolate a client, it is important to consider the client's decreased social contact and lack 
of environmental stimulation. This isolation may increase confusion in older adults (Timby and Smith, 2014).

The study findings revealed that more than half of staff nurses had inadequate practice regarding total general infection control measures. A large proportion of acquired infection in the hospital has been attributed to cross contamination and transmission of microbes from the hand of health care workers to patients. Many studies have consistently shown that improved hand hygiene practice reduced nosocomial infections and cross-transmission of multi -drug resistant infections in the hospital (Shinde and Mohite, 2014).

Regarding the total practice of specific infection control, the study finding revealed that most staff nurses had inadequate practice. The current result may be explained by present study results, which clarified that most nurses had inadequate practice regarding all specific areas as well as prevention/control of respiratory infection, endotracheal suction, medication and fluids, prevention/control of urinary infection and prevention/control of IV-device related infection, meanwhile no one of studied staff nurses had practice about prevention/control of wound infection and chest tube.

Concerning the relationship between knowledge and practice among staff nurses; the study findings indicated that no statistically significant correlation between nurse knowledge and practice scores. The researcher point of view might be due to unavailability of resources and no restrict policy and continues education about infection control. The study finding consistent with El-Sayed et al., (2015) who indicated that there was no significant relationship was found in relation to knowledge and practice of infection control measures application among participants.

Also, Hibbert (2011) reported that untrained staff nurses cannot be able to provide good practice. Study findings were incongruent with Fahim et al., (2011) who illustrated that there was a positive significant statistical relation between knowledge and nurses good performance.

In conclusion, the study finding revealed that there was a statistically significant relation between practice and number of services provided. Also, knowledge scores and practice scores had statistical significant relation with a number of equipment and supplies available. The current results were supported by Najeeb \& Taneepanichsakul (2008) who revealed that nursing practice is not only influenced by knowledge, but 
also by organizational factors such as nursing staff to patients' ratio and sufficient supplies that help to achieve the goal of infection prevention. As well, lack of nurses' training and lack of facilities in the unit they work.

\section{CONCLUSION:}

\section{Based on study findings, it can be concluded that:}

In the light of the main study findings, it was concluded that the majority of staff nurses had unsatisfactory knowledge and had inadequate practice in most areas of infection control. Moreover, there were statistically significant relationships between staff nurses' practice and age, years of experience and the number of services provided. Meanwhile, there were no significant relations detected between nurses' knowledge and personal and job characteristics of staff nurses. Furthermore, the study showed that there was no statistically significant relationship between staff nurses' knowledge and practice regarding infection control.

\section{RECOMMENDATIONS:}

Based on the results of the present study, the following recommendations were suggested:

1- Instruct and force staff nurses in order to follow the instructions about infection control measures.

2- Training course program is necessary to increase nurses' knowledge and practice towards nosocomial infection control measures regularly.

3- Force the rule of discipline when nurses do not follow the infection control measures in their pactice.

4- Conducting an orientation program for the new staff members nurses about the infection control measures

5- Posters, charts, handouts and snippets of these guidelines displayed on strategic places/points of the hospital. Moreover, infection-control measure guidelines must be updated frequently. 


\section{REFERENCES:}

Abd El-Azem, A.K. (2013): Assessment of nursing performance regarding infection control measures with central venous catheter. Unpublished thesis, Suez Canal Un., Fac. Ng., M.Sc.,108.

Al-Jubouri, M.B. (2014): Assessment of Nurse's Knowledge about Nosocomial Infection at Hospitals in Baghdad City. Journal of Kufa for Nursing Science, 4(1): 4-5.

Amoran, O.E. and Onwube, O.O. (2013): Infection control and practice of standard precautions among health care workers in northern Nigeria, J. Nursing Education, 3(5): 156-163.

Cardo, D., Halverson, P., Fishman, N., Kohn, M. and Murphy, C. (2010): Moving toward elimination of healthcare-associated infections, Am .J. Infect. Control., 4(1): p. 671.

El-Sayed, Z.M., Gomaa, A. and Abdel-Aziz, M. (2015): Nurses' Knowledge and Practice for Prevention of Infection in Burn Unit at a University Hospital: Suggested Nursing Guidelines. Journal of Nursing and Health Science, 4(4): 66-67.

Ezz El-Deen (2010): Assessment of knowledge and practice of emergency nurses regarding infection control in public and private hospitals. Unpublished thesis, Suez Canal Un., Fac. Ng., M.Sc.,114-116.

Fahim, M.F., Hekmat, I.A., Salwa A.M. and Heba, B.S. (2011): Nurses practices regarding to infection control during vaccinationin children at El- Minia. Journal of Nursing and Health Science, 4(3):62-69.

Faris, H.I. and Hassan, H.B. (2016): Evaluation of Nurses Practices Concerning Sterile Techniques Critical Care Units in Al-Najaf AL-Ashraff City Hospitals. International Journal of Scientific and Research Publications,6(6): 698-700. 
Fashafsheh, I., Ayed, A., Eqtait, F. and Harazneh, L. (2015): Knowledge and Practice of Nursing Staff towards Infection Control Measures in the Palestinian Hospitals. Journal of Education and Practice, 6(4):88.

Gizaw, G.D., Z.A. and Kibret, K.T. (2014): Assessment of knowledge and practice of health workers towards tuberculosis infection control and associated factors in public health facilities of Addis Ababa, Ethiopia: A cross-sectional study, 55.

Hibbert, A. (2011). Stress in surgical patients. A physiological perspective. J. Surgical Nursing, advanced practice, Edinburgh, Churchill, Livingstone, 23(4): 152-167.

Najeeb, N. and Taneepanichsakul, S. (2008): Knowledge, attitude, and practice of standard and transmission-based precautions of doctors and nurses in tertiary and secondary health care settings of Maldives. Journal of Health Research, 22(2): 45-48.

Park, K. (2008): Park's Textbook of Preventive and Social Medicine. $20^{\text {th }}$ ed, 313.

Patel, A.S., White-Comstock, M.B., Woolard, C.D. and Perz, J.F. (2009): "Infection control practices in assisted living facilities: a response to hepatitis B virus infection outbreaks". J. Infection Control \& Hospital Epidemiology, 5(1): 209-214.

Shinde, M.B. and Mohite, V.R. (2014): A Study to Assess Knowledge, Attitude and Practices of Five Moments of Hand Hygiene among Nursing Staff and Students at a Tertiary Care Hospital at Karad. International Journal of Science and Research, 3(2): 311-319.

Siegel, J.D., Rhinehart, E., Jackson, M., Chiarello, L. and the Healthcare Infection Control Practices Advisory Committee (2007): Guidelines for Isolation Precautions: Preventing Transmission of Infectious Agents in Healthcare Settings. J. of education and practice, 6(4): 40-45.

Sliman, W.M.M. (2005): Assessment of intensive care unit nurses knowledge and practice of infection control precautions. Un published Master Thesis, Zagazig Un., Fac. Ng., M.SC; 11. 
Smeltzer, S.C.C., Bare, B.G., Hinkle, J.L. and Cheever, K.H. (2010): Brunner and Suddarth's textbook of medical-surgical nursing, $3^{\text {rd }}$. ed., Lippincott Williams \& Wilkins. New York: 2121

Teshager, F.A., Engeda, E.H. and Worku, W.Z. (2015): Knowledge, Practice, and Associated Factors towards Prevention of Surgical Site Infection among Nurses Working in Amhara Regional State Referral Hospitals, Northwest Ethiopia. 3-4. Available at https://www.ncbi.nlm.nih.gov/pmc/articles/PMC4693022/

Timby, B. K. and Smith, N. E. (2014): Introductory medical surgical nursing. $11^{\text {th }}$. ed., New York: Lippincott Williams\& Wilkins; 127-128.

Varshney, A.M., Ahmad, S., Bansal, R., Sharma, S. and Parashar, P. (2014): "Awareness about Nosocomial Infections among Nurses and Healthcare Workers of Hospital in Meerut Up". Asian Pacific Journal of Nursing, 38(5): 46-51.

World Health Organization WHO (2009): Guidelines on Hand Hygiene in Health Care. Available at http://www.who.int/patientsafety/ information center/documents/ /index.html 


\section{تقيّيـم مـعلـومـات ممارسات ممرضات مسـتشفى منـيـة النصـر المـركزى \\ عـن اجراءات التحكم}

سحر السيد فوزى ـ أ.م.د/وفاء فتحى سليم ـ أ.م.د/ايمان صالح شاهين - م/ هند عبد الله محمد

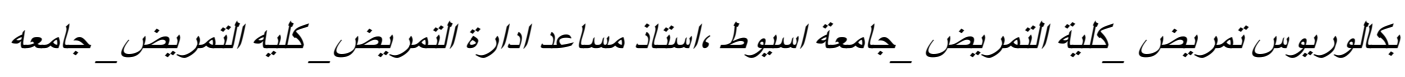

المنصوره، استاذ مساعد تصريض الباطنى والجراحى_كلية التصريض _جامعة بورسعبد، مدرس ادارة التمريض_كلبة التصريض_جامعة بورسعبي.

\section{الـخـلاصـــة}

غالبا ما يتعرض اعضاء الفريق التمريضى للعديد من العدوى خلال تقديم الرعاية التمريضية للمرضى. لذالك يجب على التمريض ان يكون لديهم معلومات ومهارات عن مكافحة العدوى بالمستشفيات. الـهدف مسن السـراســة: تهدف هذه الدراسة إلى تقييم معرفـة وممارسـات الممرضين فيما يتعلق بمكافحة العدوى. وقد نم

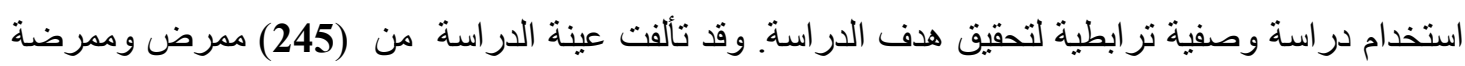

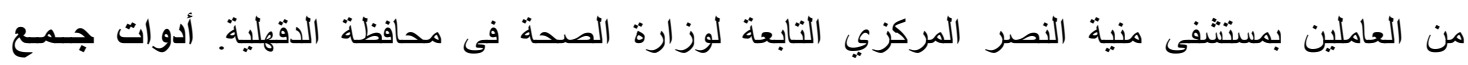
الـبـيـاتــات: استمارة استبيان لتقييم معلومات التمريض عن مكافحة العدوى و استمارة ملاحظة لتقييم الممارسات. الـنــائسج: أظهرت النتائج أن غالبية التمريض لديهم معرفة غير مرضية و ايضـا ممارسات غير كافية فيما

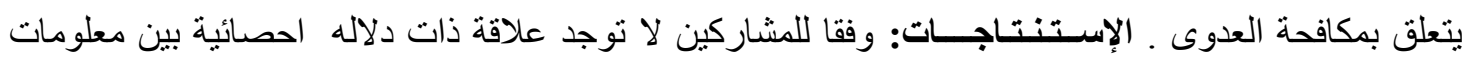

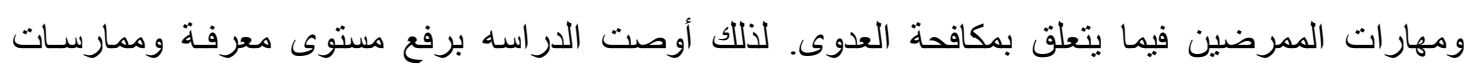

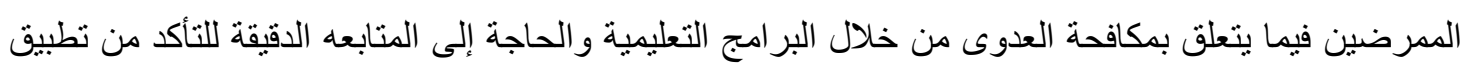

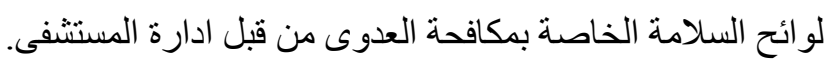
الكلمات المرشدة : مكافحة العدوى، المعرفة، الممارسات ، الممرضات 